\title{
The Effectiveness Testing of L-Carnitine on the Quality of Spermatozoa and Testosterone Hormone in White Rats (Rattus norvegicus) Feeding with High Fat
}

\author{
Ni Wayan Sukma Antari \\ Institut Teknologi dan Kesehatan Bali, Indonesia \\ Corresponding author email: sukma.antari91@gmail.com \\ Ida Ayu Manik Damayanti \\ Institut Teknologi dan Kesehatan Bali, Indonesia \\ Nadya Treesna Wulansari \\ Institut Teknologi dan Kesehatan Bali, Indonesia
}

\begin{abstract}
This study aims to determine the increase in the quality of spermatozoa and testosterone after giving Lcarnitine to white rats (Rattus norvegicus). This study was conducted by giving L-carnitine as a treatment for 42 days in white rats with a dose variation of $100 \mathrm{mg} / \mathrm{kg} \mathrm{bw}, 150 \mathrm{mg} / \mathrm{kg} \mathrm{bw}$, and $200 \mathrm{mg} / \mathrm{kg}$ bw and user controls as a comparison. The variables observed in this study were the quality of spermatozoa, namely: morphology, motility, viability, membrane integrity, and seeing the levels of the hormone testosterone. The research data were processed using a computer statistical program (SPSS 22.0 for Windows) using the One Way Anova test. The results showed that giving high doses of L-carnitine supplements for a long time could cause decreased spermatozoa quality, namely: morphology, motility, viability, membrane integrity and decreased levels of the hormone testosterone.
\end{abstract}

Keywords---quality of spermatozoa, testosterone L-carnitine hormone, white rats.

\section{Introduction}

One of the disorders of male reproductive health that occurs at childbearing age is infertility. Infertility is the inability to conceive and give birth to a live baby after one year of regular intercourse and not using any contraceptives (Djuwantono, 2008). Alternative medicine to treat infertility is being intensively carried out. Many studies have been conducted to identify natural substances that can protect the body from oxidative stress such as the use of antioxidant compounds found in fruits, vegetables, whole grains, and health supplements. One of the ingredients in health supplements that can be used as an alternative to infertility treatment is L-carnitine.

The content of L-carnitine is a substance derived from the essential amino acids methionine and lysine which have vitamin-like properties but cannot be categorized as a vitamin. L-carnitine, which is often consumed for the process of burning body fat, turns out to be an essential substance that can increase male fertility because of its ability to help increase energy metabolism and maturation of spermatozoa (Vicari et al., 2001; Dorado et al., 2011; Ciereszko et al., 2000; Ermayanti et al., 2016). Therefore, it is necessary to research the infertility test by looking at the quality of spermatozoa which includes motility, morphology, viability, the integrity of the spermatozoa membrane, and measuring the levels of the hormone testosterone in male white rats (Rattus norvegicus) by giving pure L-carnitine. 


\section{Methods}

This research was conducted by giving L-carnitine as a treatment for 42 days to white rats. The research design used a completely randomized design (CRD) which consisted of four groups where one control group and three treatment groups (Figure 1). The grouping was done randomly. Each group will be given treatment orally for 42 days based on 1 cycle of spermatogenesis in rats.

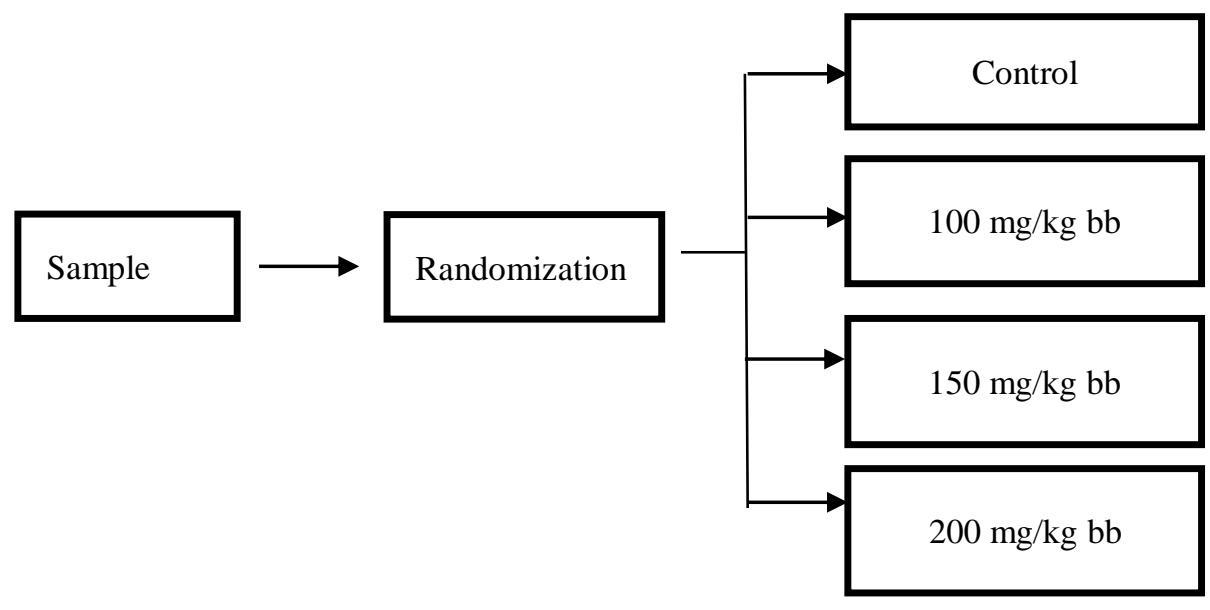

Figure 1. Research design

Schematic description:

Control

$100 \mathrm{mg} / \mathrm{kg}$ body weight L-carnitine

$150 \mathrm{mg} / \mathrm{kg}$ body weight L-carnitine

$200 \mathrm{mg} / \mathrm{kg}$ bw L-carnitine male mice were given mineral water without L-carnitine orally as much as $1 \mathrm{~mL} /$ day for 42 days

Male rats were given L-carnitine at a dose of $100 \mathrm{mg} / \mathrm{kg} \mathrm{BW}$ orally as much as $1 \mathrm{~mL} /$ day for 42 days.

Male rats were given L-carnitine at a dose of $150 \mathrm{mg} / \mathrm{kg} \mathrm{BW}$ orally as much as $1 \mathrm{~mL} /$ day for 42 days.

On the 42nd day, the rats were sacrificed and then operated on, the rats were sacrificed using chloroform and dissected in the abdomen, then the testes were cleaned from other tissues. The cauda epididymis was taken. For testing the testosterone hormone using blood taken from the heart, measuring the hormone levels using KIT ELISA.

\section{Collections of epididymal spermatozoa}

The cauda epididymis was cut and chopped in $1 \mathrm{~mL}$ of $0.9 \% \mathrm{NaCl}$ solution with a $\mathrm{pH}$ of 7.2-7.4 using scissors to form a suspension of spermatozoa. Spermatozoa fluid is used to measure sperm quality which consists of:

a) Spermatozoa motility

b) Morphology of spermatozoa

c) Viability of spermatozoa

d) Spermatozoa membrane integrity

\section{Results}

Research conducted using supplements containing L-Carnitine as an ingredient to improve the quality of spermatozoa and testosterone hormone levels after research was carried out by giving supplements containing LCarnitine to male white rats with doses according to the steps in a predetermined research design (Antari et al., 2016; Ri, 2013; Sherwood, 2011). The research data was tested using SPSS 21.0 where the results obtained using the Kolmogrov-Smirnov test showed that the data were not normally distributed with a value of $\mathrm{P}<0.05$, then a homogeneity test was carried out which showed that the data was not homogeneous, with a P-value $<0.05$. After that, 
it was continued with the Kruskal-Wallis test to determine the significant value of the test results. The statistical test results will be described below:

\section{Effect of L-Carnitine on sperm motility}

In the measurement results of the measured motility speed on 100 spermatozoa cells with 3 times of repetition and using 2 categories, namely:

A: spermatozoa that move fast forward

B: spermatozoa moving in place

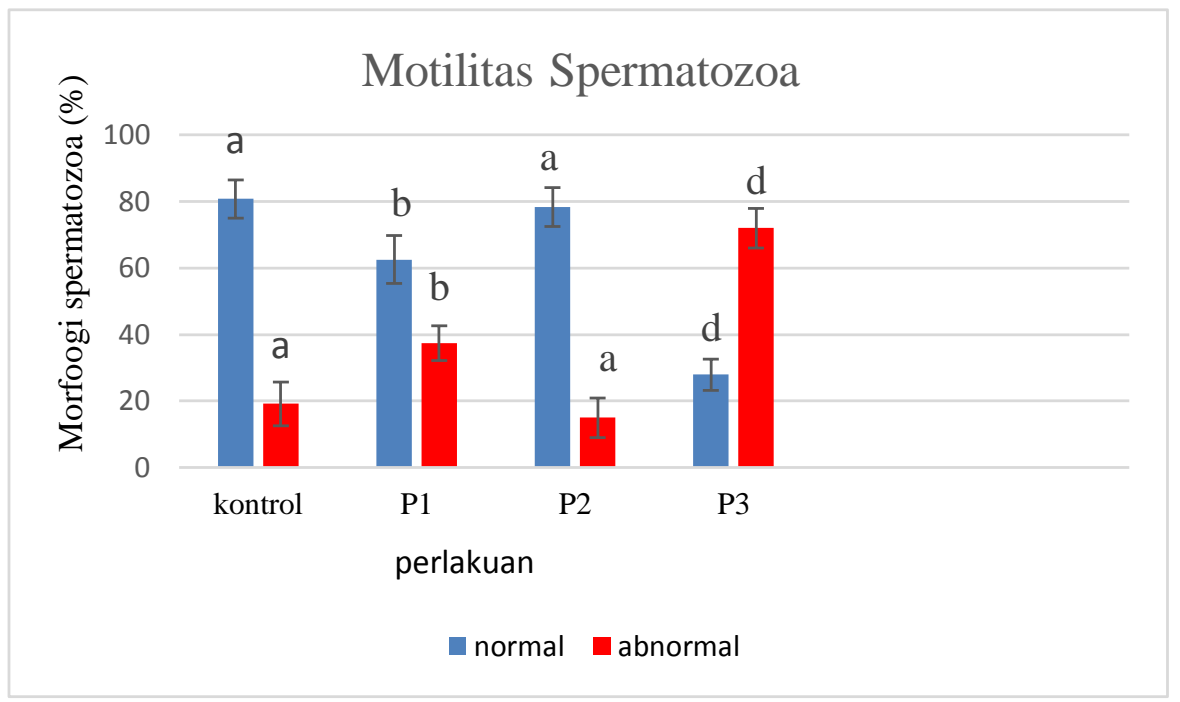

Figure 2. Effect of L-Carnitine on sperm motility where the value of an in Control and P2 shows insignificant results. Meanwhile, letters a, b, and c indicate a significant difference between the control group with P1 and P3 with a value of $\mathrm{P}<0.05$

\section{Effect of L-Carnitine on the morphology of spermatozoa}

The results of the calculation of sperm morphology were carried out using a light microscope with a magnification of 40x10, where the morphological calculations of the spermatozoa were divided into 2 categories, namely:

A: Normal spermatozoa are characterized by a head that is shaped like a hook or crescent moon, a complete and straight tail

B: Characterized by a severed head, the presence of cytoplasmic droplets remaining in the spermatozoa cell membrane, a curved and broken tail.

\section{Effect of L-Carnitine on the morphology of spermatozoa}

The results of the calculation of sperm morphology were carried out using a light microscope with a magnification of 40x10, where the morphological calculations of the spermatozoa were divided into 2 categories, namely:

A: Normal spermatozoa are characterized by a head that is shaped like a hook or crescent moon, a complete and straight tail

B: Characterized by a severed head, the presence of cytoplasmic droplets remaining in the spermatozoa cell membrane, a curved and broken tail. 


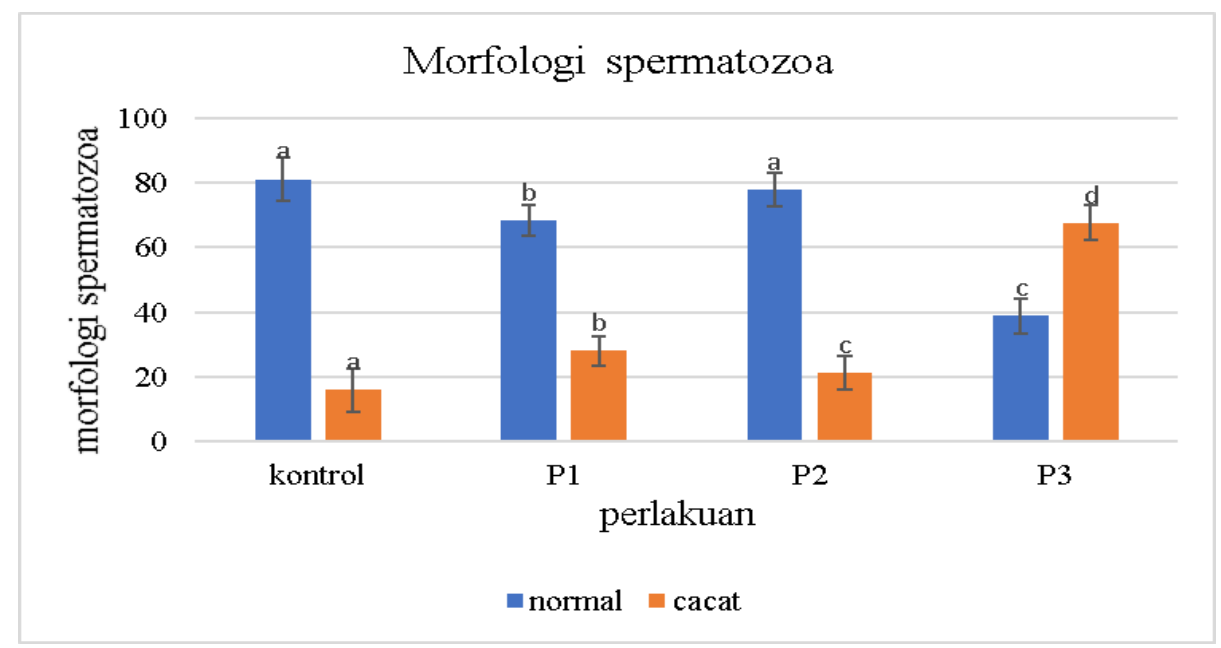

Figure 3. Effect of L-Carnitine on spermatozoa morphology where the value of an in Control and P2 shows insignificant results. Meanwhile, letters a, b and c indicate a significant difference between the control group with P1 and $\mathrm{P} 3$ with a value of $\mathrm{P}<0.05$

\section{Effect of L-Carnitine on the viability of spermatozoa}

Measurement of the viability of spermatozoa was carried out using a light microscope with a 400x magnification on 100 spermatozoa cells (Karadeniz et al., 008; Matalliotakis \& Koumantakis, 2000). Dead spermatozoa are characterized by the absorption of $1 \%$ Eosin and $10 \%$ Nigrosin dyes while living spermatozoa are characterized by no color absorption (clear).

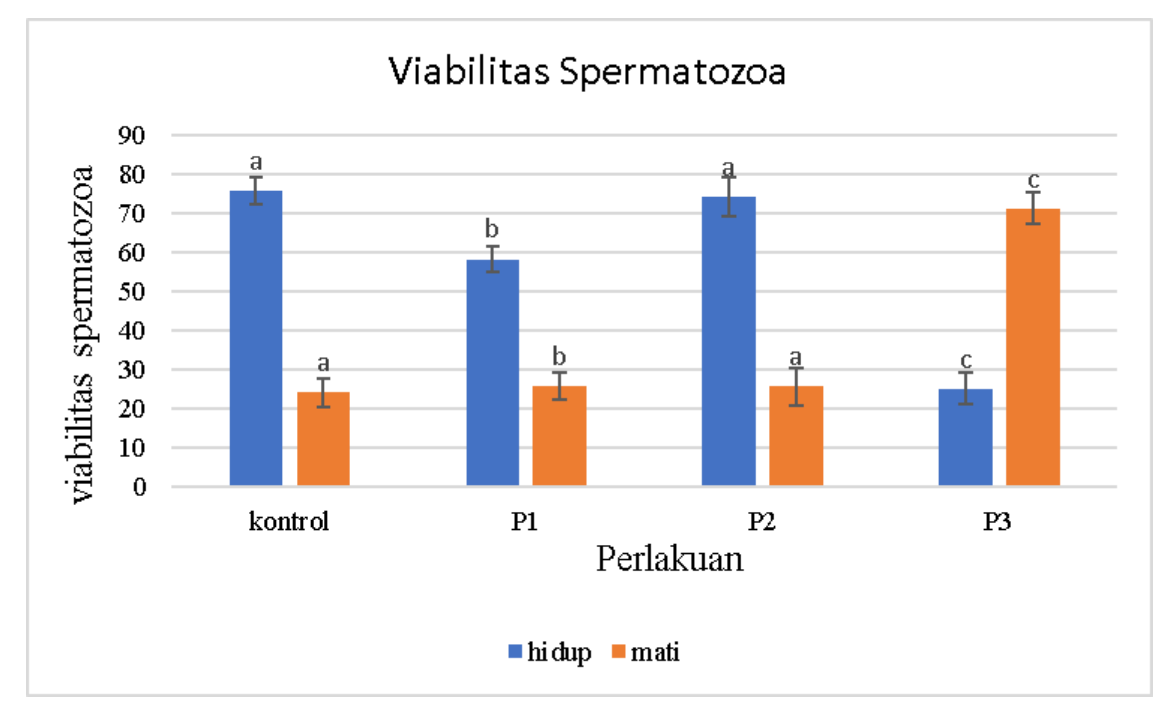

Figure 4. Effect of L-Carnitine on the viability of spermatozoa where the value of an in Control and P2 shows insignificant results. Meanwhile, letters a, b, and c indicate a significant difference between the control group with $\mathrm{P} 1$ and $\mathrm{P} 3$ with a value of $\mathrm{P}<0.05$

\section{Effect of L-Carnitine on the integrity of the spermatozoa membrane}

Observation of the integrity of the spermatozoa membrane was carried out using a light microscope with a 400x magnification of 100 spermatozoa cells. Good spermatozoa membrane integrity can be seen from the swelling and coiling of the tail, while the damaged (poor) sperm membrane integrity can be seen from the absence of swelling and a straight tail. 


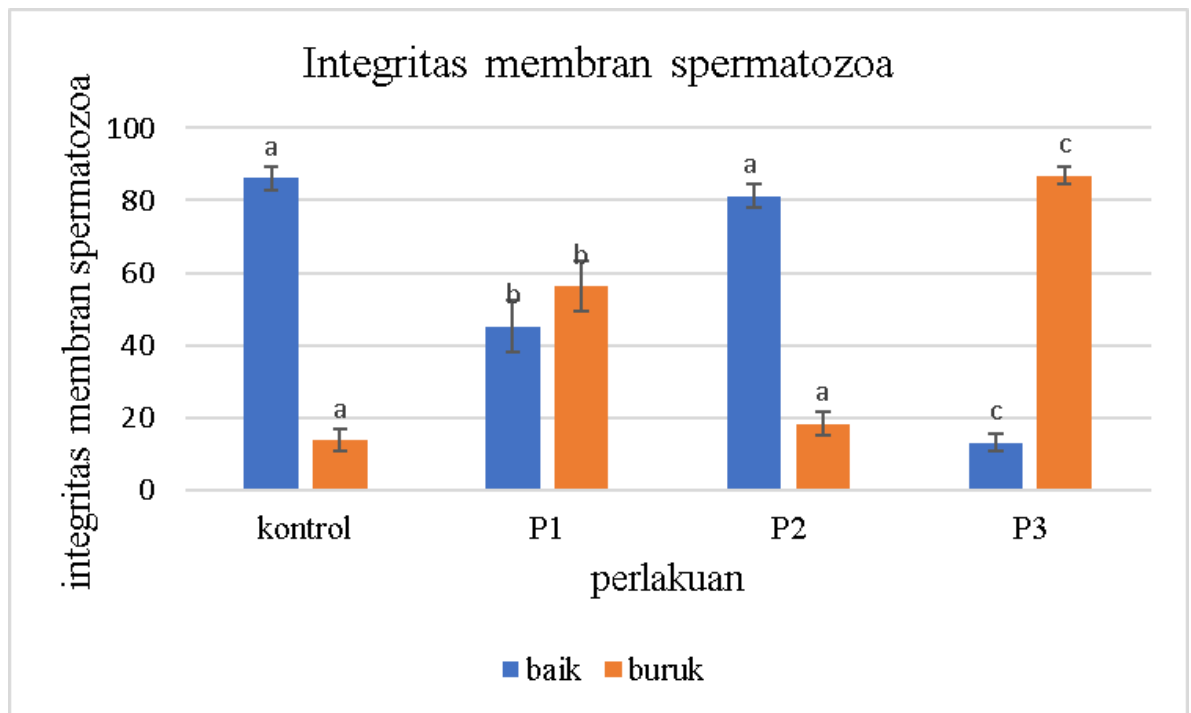

Figure 5. Effect of L-Carnitine on the integrity of spermatozoa where the value of an in Control and P2 shows insignificant results. Meanwhile, letters $\mathrm{a}, \mathrm{b}$ and $\mathrm{c}$ indicate a significant difference between the control group with P1 and $\mathrm{P} 3$ with a value of $\mathrm{P}<0.05$

\section{Effect of L-Carnitine on Testosterone Hormone Levels}

Testosterone levels were calculated using the Enzyme-Linked Immunosorbent Assay (ELISA) method. The absorbance value of the ELISA results was calculated using an ELISA reader at a wavelength of $450 \mathrm{~nm}$.

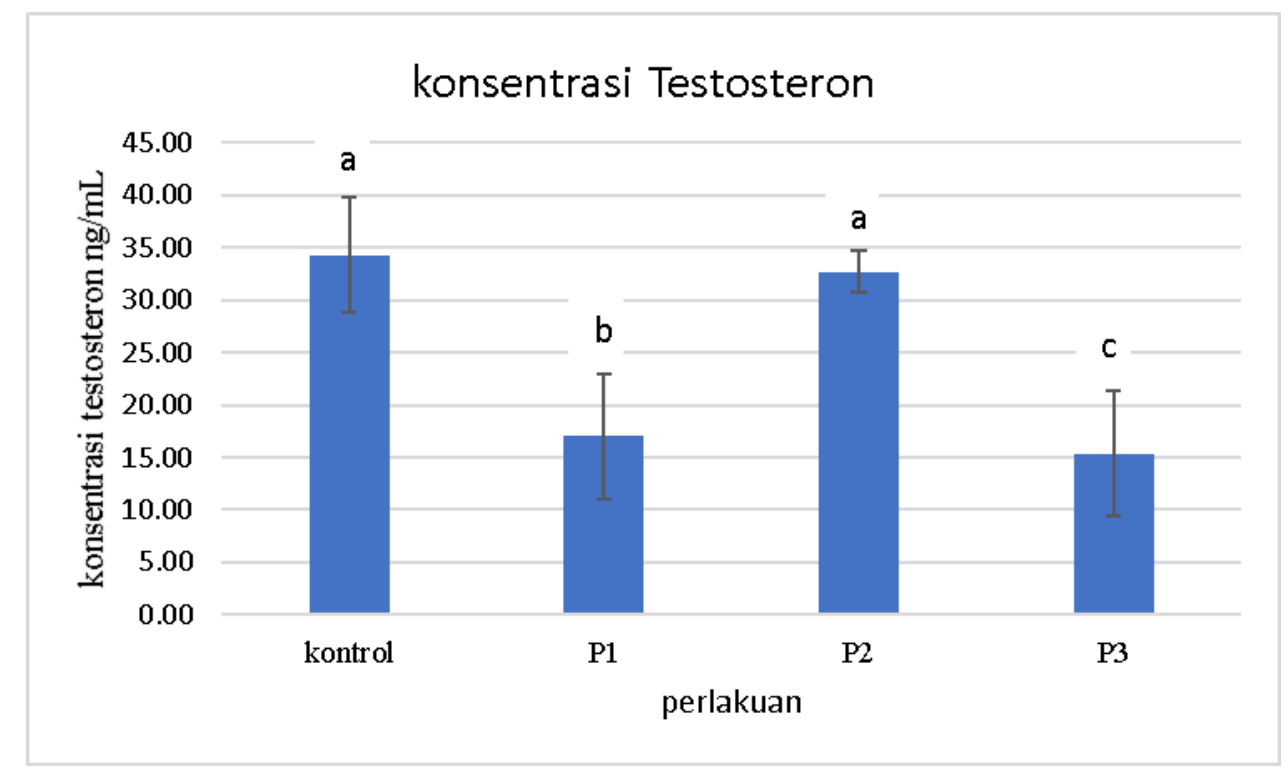

Figure 6. Effect of L-Carnitine on testosterone levels where the value of an in Control and P2 shows insignificant results. Meanwhile, letters a, b, and c indicate a significant difference between the control group with P1 and P3 with a value of $\mathrm{P}<0.05$

\section{Discussion}

In this study, L-carnitine has an increased effect on the motility of spermatozoa group A, namely spermatozoa that move fast forward, but at certain doses, namely in the study used a dose of $200 \mathrm{Mg} / \mathrm{bb}$ showed a decreased effect on 
the motility of class A spermatozoa. This is because L-carnitine is toxic if consumed in excessive amounts. LCarnitine plays a role in the transport of long-chain fatty acids into the mitochondria for oxidation (Chatzifotis \& Takeuchi, 1997; Owen et al., 2001), regulation of the CoA / CoA-SH ratio which is important in the catabolism of carbohydrates and fats and the rate of the Krebs cycle (Chatzifotis et al., 1996; Vaz et al., 2002). The provision of Lcarnitine in feed can increase the protein-sparing action of fat, so that energy from protein is mostly used for body protein synthesis.

The movement of the spermatozoa tail is controlled by the driving part or dynein (outer dynein arm and inner dynein arm) and the radial spokes that compose the microtubules. The movement of spermatozoa uses the energy generated from the mitochondria, where the mitochondria are arranged spirally and are protected by the cell membrane. Mitochondria will produce energy through the ATP hydrolysis process where the movement occurs by converting chemical energy into kinetic energy through the enzyme ATP-ase (Hayati, 2011).

L-Carnitine with high levels in spermatozoa results in high levels of ROS, high levels of ROS resulting from reduced oxidants causing oxidative stress, resulting in the cell membrane protecting the mitochondria in the tail being damaged and disrupting the function of the mitochondria in producing ATP for movement (Hoek et al., 2002; Neuman et al., 2002; NG et al., 2004).

The ATP-ase enzyme maintains internal homeostasis for sodium and potassium ions. If the activity of the ATPase enzyme is disturbed, the homeostasis of sodium and potassium ions will be disturbed so that the intracellular $\mathrm{Na}$ + concentration increases, the $\mathrm{Na}+$ gradient across the cell membrane will decrease, so that the release of $\mathrm{Ca} 2+$ will also decrease (Ganong, 2001). If the $\mathrm{Ca} 2+$ ion is reduced, the membrane will lose its ability to transport dissolved materials into the cytoplasm (Haryati, 2003). The disruption of the permeability of the sperm membrane will disrupt the transport of nutrients needed by spermatozoa for their movement.

The analysis of spermatozoa morphology in this study showed that the morphological results in the control group and P2 were not significant, this shows that L-Carnitine with the appropriate dose wherein the study a dose of 150 $\mathrm{Mg} / \mathrm{bb}$ was used can improve normal morphology. In this case, L-Carnitine can stimulate androgen hormones so that it can increase the normal spermatogenesis process and the maturation of spermatozoa (Suharyati \& Hartono, 2013; Mohammadi et al., 2021; Sundseth \& Waxman, 1992).

The P3 group showed a decrease in normal morphology and increased abnormal morphology in male white rat spermatozoa, this was due to the high dose of L-carnitine consumed which caused damage during the spermatogenesis process due to high levels of ROS in the testes resulting in damage to the cell membrane. From the seminiferous tubules so that toxic free radicals can enter the seminiferous tubules. Increased levels of ROS will result in oxidative stress due to high ROS levels and antioxidants are not able to reduce oxidant levels, causing damage to cells, tissues, and organs. There are primary and secondary abnormalities in spermatozoa, where the primary abnormalities are visible in the form of small heads, amorphous heads, and spiral tails, while the secondary abnormalities were seen are spermatozoa without a head and a tail. This is because ROS affects the spermatozoa plasma membrane which contains large amounts of phospholipids and unsaturated fatty acids, where unsaturated fatty acids are susceptible to ROS, especially hydroxyl radicals which are the most reactive derivatives, this is because hydroxyl radicals will cause a chain reaction called lipid peroxidation. Thus resulting in breaking the chain of fatty acids into compounds that are toxic to spermatozoa cells (Murray, 2007).

The increase in the quality of male spermatozoa given L-Carnitine is due to the effectiveness of L-Carnitine as a powerful antioxidant and prevents the formation of free radicals in sperm formation (Agarwal \& Said, 2004). This can be explained by the presence of high amounts of long-chain polyunsaturated fatty acids (PUFAs) in the spermatozoa membrane. Peroxides cause fundamental changes in the composition of the sperm, especially the acrosome area, and cause a significant reduction in the viability and integrity of the spermatozoon membrane. Free radicals reduce the quality of spermatozoa and prevent the acrosome reaction with the membrane (Aitken \& Clarkson, 1987; Aitken et al., 1993). The role of L-Carnitine in improving spermatozoa quality is to prevent the formation of free radicals, which form peroxides that cause oxidation of the spermatozoa membrane (Sarica et al., 2007).

Supplementation containing L-Carnitine has a role in stimulating an increase in follicle-stimulating hormone (FSH) and luteinizing hormone (LH). This is evidenced by the increase in the concentration of FSH, LH, and testosterone in blood serum. FSH is directly responsible for stimulating the spermatogenesis process, increasing testis size, differentiation of Sertoli cells, and seminiferous tubule size (O'Shaughnessy et al., 2010). On the other hand, LH plays a basic role in the differentiation and maturation of Leydig cells and the production of testosterone in the interstitial tissue of the testes. Testosterone has an important role in spermatogenesis and in improving the quality and quantity of semen. High concentrations of this hormone promote testicular growth and maintenance (Jacyno et al., 2007). 


\section{Conclusion}

Providing high doses of L-carnitine supplements for a long time can cause a decrease in the quality of spermatozoa which includes: morphology, motility, viability, and integrity of the spermatozoa membrane, as well as lowering levels of the hormone testosterone in the blood.

\section{References}

Agarwal, A., \& Said, T. M. (2004). Carnitines and male infertility. Reproductive biomedicine online, 8(4), 376-384. https://doi.org/10.1016/S1472-6483(10)60920-0

Antari, N. W. S., Hayati, A., \& Winarni, D. (2016). Provision of Arak Reduces Spermatozoa Quality of White Rats (Rattus norvegicus). Folia Medica Indonesiana, 52(4), 235-240.

Chatzifotis, S., \& Takeuchi, T. (1997). Effect of supplemental carnitine on body weight loss, proximate and lipid compositions and carnitine content of red sea bream (Pagrus major) during starvation. Aquaculture, 158(1-2), 129-140. https://doi.org/10.1016/S0044-8486(97)00175-0

Chatzifotis, S., Takeuchi, T., \& Seikai, T. (1996). The effect of dietary carnitine supplementation on growth of red sea bream (Pagrus major) fingerlings at two levels of dietary lysine. Aquaculture, 147(3-4), 235-248. https://doi.org/10.1016/S0044-8486(96)01403-2

Ciereszko, A., Ottobre, J. S., \& Glogowski, J. (2000). Effects of season and breed on sperm acrosin activity and semen quality of boars. Animal reproduction science,64(1-2), 89-96. https://doi.org/10.1016/S03784320(00)00194-9

Djuwantono, T. (2008). Hanya 7 hari memahami infertilitas. Bandung: PT. Refika Aditama.

Dorado, J., Alcaráz, L., Duarte, N., Portero, J. M., Acha, D., Demyda, S., ... \& Hidalgo, M. (2011). Centrifugation on PureSperm ${ }^{\circledR}$ density-gradient improved quality of spermatozoa from frozen-thawed dog semen. Theriogenology, 76(2), 381-385. https://doi.org/10.1016/j.theriogenology.2011.02.026

Ermayanti, N. G. A. M., Oka, I. G. L., Mahardika, I. G., \& Suyadnya, I. P. (2016). Free testosterone level and quality of cauda epididymis sperm of local rabbit that given commercial feed supplemented by cod fish liver oil. International Research Journal of Engineering, IT and Scientific Research, 2(3), 1-8.

Ganong, W.F. 2001. Buku Ajar Fisiologi Kedokteran. Penerbit Buku Kedokteran EGC. Jakarta

Haryati, N. (2003). Pengaruh Suhu dan Lama Penyimpanan Sosis Daging Sapi Terhadap Total Bakteri dan Penilaian Organoleptik (Doctoral dissertation, Diponegoro University).

Hayati, A. (2011). Spermatologi. Surabaya: Pusat Penerbitan dan Percetakan Unair.

Hoek, E., Carranza-Torres, C., \& Corkum, B. (2002). Hoek-Brown failure criterion-2002 edition. Proceedings of NARMS-Tac, 1(1), 267-273.

Jacyno, E., Kołodziej, A., Kamyczek, M., Kawęcka, M., Dziadek, K., \& Pietruszka, A. (2007). Effect of L-carnitine supplementation on boar semen quality. Acta Veterinaria Brno, 76(4), 595-600.

Karadeniz, A., Simsek, N., \& Cakir, S. (2008). Haematological effects of dietary L-carnitine supplementation in broiler chickens. Revue Méd. Vét, 159(8-9), 437-444.

Matalliotakis, I. \& Koumantakis, E. (2000). L-carnitine levels in the seminal plasma of fertile and infertile men: correlation with sperm quality. Int. J. Fert. Womens Med. 45, 236-240.

Mohammadi, V., Sharifi, S. D., Sharafi, M., Mohammadi-Sangcheshmeh, A., Shahverdi, A., \& Alizadeh, A. (2021). Manipulation of fatty acid profiles in roosters' testes, alteration in sexual hormones, improvements in testicular histology characteristics and elevation sperm quality factor by L-carnitine. Theriogenology, 161, 8-15. https://doi.org/10.1016/j.theriogenology.2020.10.005

Murray, G. M. (2007). Acrosome size and kinematics of human spermatozoa (Doctoral dissertation, Stellenbosch: University of Stellenbosch).

Neuman, S. L., Lin, T. L., \& Heste, P. Y. (2002). The effect of dietary carnitine on semen traits of White Leghorn roosters. Poultry Science, 81(4), 495-503. https://doi.org/10.1093/ps/81.4.495

NG, C. M., Blackman, M. R., Wang, C., \& Swerdloff, R. S. (2004). The role of carnitine in the male reproductive system. Annals of the New York Academy of Sciences, 1033(1), 177-188.

O'shaughnessy, P. J., Monteiro, A., Verhoeven, G., De Gendt, K., \& Abel, M. H. (2010). Effect of FSH on testicular morphology and spermatogenesis in gonadotrophin-deficient hypogonadal mice lacking androgen receptors. Reproduction (Cambridge, England), 139(1), 177. 
Owen, K. Q., Jit, H., Maxwell, C. V., Nelssen, J. L., Goodband, R. D., Tokach, M. D., .. \& Koo, S. I. (2001). Dietary L-carnitine suppresses mitochondrial branched-chain keto acid dehydrogenase activity and enhances protein accretion and carcass characteristics of swine. Journal of Animal Science, 79(12), 3104-3112.

Ri, K. (2013). Riset kesehatan dasar. Jakarta: Badan Penelitian dan pengembangan Kesehatan Kementrian Kesehatan RI.

Sarica, M., Ocak, N., Karacay, N., Yamak, U., Kop, C. A. N. A. N., \& Altop, A. (2009). Growth, slaughter and gastrointestinal tract traits of three turkey genotypes under barn and free-range housing systems. British Poultry Science, 50(4), 487-494.

Sherwood, L. (2011). Fisiologi manusia dari sel ke sistem edisi 6. Alih bahasa: brahm U. Editor Nella Yesdelita. Jakarta: EGC.

Suharyati, S., \& Hartono, M. (2013). Peningkatan kualitas semen kambing Boer dengan pemberian Vitamin E dan Mineral Zn. Jurnal Kedokteran Hewan-Indonesian Journal of Veterinary Sciences, 7(2).

Sundseth, S. S., \& Waxman, D. J. (1992). Sex-dependent expression and clofibrate inducibility of cytochrome P450 4A fatty acid omega-hydroxylases. Male specificity of liver and kidney CYP4A2 mRNA and tissue-specific regulation by growth hormone and testosterone. Journal of Biological Chemistry, 267(6), 3915-3921. https://doi.org/10.1016/S0021-9258(19)50613-5

Vaz, G., Roussouly, P., Berthonnaud, E., \& Dimnet, J. (2002). Sagittal morphology and equilibrium of pelvis and spine. European spine journal, 11(1), 80-87.

Vicari, E., \& Calogero, A. E. (2001). Effects of treatment with carnitines in infertile patients with prostato-vesiculoepididymitis. Human Reproduction, 16(11), 2338-2342. 